PENERAPAN MODEL PEMBELAJARAN KOOPERATIF TIPE TEAMS GAMES TOURNAMENT (TGT) BERBANTUAN MEDIA GAMBAR DAN TEKA-TEKI SILANG UNTUK MENINGKATKAN MOTIVASI DAN HASIL BELAJAR PADA MATA PELAJARAN PKn SISWA KELAS VIII.6 SMP NEGERI 3 BANJAR TAHUN AJARAN 2013/2014

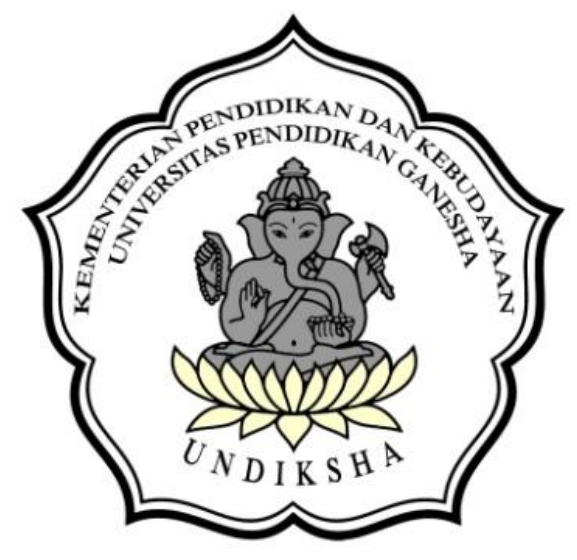

ARTIKEL

\author{
Oleh \\ Ni Putu Ratna Febriani \\ NIM 1014041051
}

JURUSAN PENDIDIKAN PANCASILA DAN KEWARGANEGARAAN

FAKULTAS ILMU SOSIAL

UNIVERSITAS PENDIDIKAN GANESHA

SINGARAJA

2014 


\title{
PENERAPAN MODEL PEMBELAJARAN KOOPERATIF TIPE TEAMS GAMES TOURNAMENT (TGT) BERBANTUAN MEDIA GAMBAR DAN TEKA-TEKI SILANG UNTUK MENINGKATKAN MOTIVASI DAN HASIL BELAJAR PADA MATA PELAJARAN PKn SISWA KELAS VIII.6 SMP NEGERI 3 BANJARTAHUN AJARAN 2013/2014
}

\author{
Oleh: \\ Ni Putu Ratna Febriani \\ Dr. I Gusti Ketut Arya Sunu, M.Pd \\ Drs. Dewa Bagus Sanjaya, M. Si \\ Jurusan Pendidikan Pancasila dan Kewarganegaraan \\ e-mail: ratna susastra@yahoo.com
}

\begin{abstract}
ABSTRAK
Penelitian ini bertujuan untuk : (1) meningkatkan motivasi belajar PKn (2) meningkatkan hasil belajar PKn, dan (3) mengetahui kendala-kendala yang dihadapi siswa dalam pembelajaran PKn melaui penerapan model pembelajaran kooperatif tipe Teams Games Tournament (TGT). Penelitian ini merupakan penelitian tindakan kelas yang dilakukan dalam dua kali siklus tindakan. Tahapan-tahapan dalam setiap siklus adalah perencanaan, pelaksanaan, obeservasi/evaluasi dan refleksi. Subjek penelitian ini adalah siswa kelas VIII 6 SMP Negeri 3 Banjar yang berjumlah 29 orang yang terdiri dari 17 orang laki-laki dan 12 orang perempuan. Objek penelitian meliputi motivasi dan hasil belajar PKn siswa. Data motivasi belajar PKn siswa dikumpulkan dengan teknik observasi dan data hasil belajar siswa dikumpulkan melalui pemberian tes. Selanjutnya data yang telah dikumpulkan dianalisis secara deskriptif kuantitatif. Hasil analisis menunjukkan bahwa 1) terjadi peningkatan skor rata-rata motivasi belajar PKn siswa siklus I sebesar $46,8 \%$ dan tergolong cukup termotivasi sedangkan skor rata-rata motivasi belajar PKn siklus II sebesar $69,7 \%$ dan tergolong termotivasi, 2) terjadi peningkatan nilai rata-rata hasil belajar PKn siswa pada siklus I sebesar 74,4 dengan daya serap yaitu $74,4 \%$ dan ketuntasan belajar secara klasikal mencapai $68,9 \%$, sedangkan nilai rata-rata hasil belajar PKn siswa pada siklus II sebesar 83,9 dengan daya serap yaitu $83,9 \%$ dan ketuntasan belajar secara klasikal mencapai $100 \%$, 3) kemampuan siswa kurang dalam mengikuti tahapan-tahapan pembelajaran model Teams Games Tournament, sehingga tahapan pembelajaran harus dijelaskan secara bertahap dan intensif. Penelitian ini sudah dapat dikatakan berhasil karena sudah memenuhi kriteria keberhasilan penelitian, yaitu skor motivasi belajar PKn siswa minimal tergolong termotivasi, nilai rata-rata hasil belajar PKn siswa diharapkan mencapai $\geq 75$, daya serap siswa mencapai $\geq 75$ dan ketuntasan belajar siswa secara klasikal $\geq 85 \%$. Berdasarkan hasil analisis data, dapat disimpulkan bahwa penerapan model pembelajaran kooperatif tipe TGT berbantuan media gambar dan teka-teki silang dapat meningkatkan motivasi dan hasil belajar PKn siswa kelas VIII.6 SMP Negeri 3 Banjar tahun ajaran 2013/2014.
\end{abstract}

Kata-kata Kunci : Teams Games Tournament (TGT), media gambar, media teka-teki silang, motivasi, dan hasil belajar. 


\title{
THE IMPLEMENTATION OF PICTURE MEDIA AND CROSSWORD PUZZLE-AIDED TEAMS GAMES TOURNAMENT TYPE COOPERATIVE LEARNING MODEL (TGT) TO IMPROVE MOTIVATION AND LEARNING ACHIEVEMENT IN CIVICS OF THE STUDENTS OF CLASS VIII. 6 AT SMP NEGERI 3 BANJAR IN THE ACADEDEMIC YEAR 2013/2014
}

\author{
Ni Putu Ratna Febriani \\ Dr. I Gusti Ketut Arya Sunu, M.Pd. \\ Drs. Dewa Bagus Sanjaya, M.Si \\ Jurusan Pendidikan Pancasila dan Kewarganegaraan
e-mail: ratna susastra@yahoo.com
}

\begin{abstract}
This study was aimed at (1) improving learning motivation to study Civics (2) improving learning achievement in Civics, and (3) finding out the constraints faced by the students in studying Civics through the implementation of The Implementation of Picture Media and Crossword Puzzle-Aided Teams Games Tournament Type Cooperative Learning Model (TGT). This study was a classroom action research that was conducted in two action cycles. The stages in each cycle were planning, action, observation/evaluation and reflection. The subjects were 26 students of Class VIII.6 at SMP Negeri 3 Banjar, consisting of 17 male students and 12 female students. The objects of the study were the student's motivation and Civics learning achievement. Data on student's Civics learning motivation were collected through a test. Then the data were analyzed descriptive-quantitatively. The results showed that 1) there was an increase in the mean score for the student's Civics learning motivation, $46.8 \%$ in cycle I (falling into "fairly motivated" category ) to $69.7 \%$ in cycle II ("motivated" category), 2) there was an increase in the mean score for the student's Civics learning achievement, 74.4 with absorptive power of $74.4 \%$ and class learning completeness of $68.9 \%$ while in cycle II, the mean score was 83.9 with absorptive power of $83.9 \%$ and class learning completeness of $100 \%$, 3) students lack the ability to follow the stages of learning models Teams Games Tournament, so the learning stages should be explained and gradually intensified. This study can be said to have been successful since it has met the study criteria of success, i.e., the minimum Civics learning motivation is in "motivated" category, the Civics learning mean score $\geq 75$, the student's mastery $\geq 75$ and the class mastery $\geq 85 \%$. Based on the result of data analysis, it can be concluded that the implementation of picture media and crossword puzzle-aided TGT type cooperative learning model can improve Civics learning motivation and achievement of the students of Class VIII.6 at SMP Negeri 3 Banjar in the academic year 2013/2014.
\end{abstract}

Keywords: Teams Games Tournament (TGT), picture media, crossword puzzle media, motivation, and learning achievement. 


\section{PENDAhULUAN}

Pendidikan merupakan salah satu cara untuk meningkatkan kualitas Sumber Daya Manusia. Pendidikan ini dilakukan dengan segala usaha yang dilaksanakan secara sadar dan bertujuan untuk mengubah manusia dari yang tidak tahu menjadi tahu. Seperti halnya yang tertuang di dalam UndangUndang No 20 Tahun 2003 (UU 20/2003) tentang Sistem Pendidikan Nasional (2003:2-3) yang menyatakan bahwa: "pendidikan adalah usaha sadar dan terencana untuk mewujudkan suasana belajar dan proses pembelajaran agar peserta didik secara aktif mengembangkan potensi dirinya untuk memiliki kekuatan spiritual keagamaan, pengendalian dirinya, kepribadian, kecerdasan, akhlak mulia, serta keterampilan yang diperlukan dirinya, masyarakat, bangsa, dan negara."

Pendidikan yang terlaksana dilingkungan sekolah atau pendidikan formal didukung oleh beberapa perangkat atau komponen-komponen yang dapat membentuk berlangsungnya kegiatan belajar mengajar tersebut seperti guru, kurikulum, media, alat peraga, sarana dan prasarana, lingkungan, alat evaluasi dan lain sebagainya. Untuk mencapai tujuan pendidikan yang diharapkan agar tercapai dengan baik maka harus terjalin interaksi dan kerjasama yang baik pula antara komponen-komponen yang ada tersebut.

Salah satu komponen yang memiliki peran yang sangat penting dalam pelaksanakan proses belajar mengajar tersebut adalah guru. Seorang guru harus mampu memahami dan mengenali karakteristik serta kebiasaan dari peserta didik dalam belajar. Dilihat dari komponen instrumental, peran guru menempati posisi strategis. Agar seorang guru dapat melaksanakan perannya sebagai pengajar dan pendidik yang baik, seorang guru harus memiliki empat kompetensi pokok, yaitu (1) kompetensi profesional, kompetensi personal/kepribadian, (3) kompetensi sosial, dan (4) kompetensi pedagogik.

Hal tersebut sangat perlu dilakukan dan dimiliki oleh seorang guru agar nantinya guru tersebut dapat menentukan model pembelajaran apa yang cocok digunakan dalam proses belajar mengajar sehingga dapat menarik bagi peserta didik dan dapat mencapai tujuan pendidikan sesuai dengan yang diharapkan. Peran strategis guru dalam proses pembelajaran ini memiliki dampak pada kompetensi yang dicapai siswa (pengetahuan, sikap, keterampilan). Kompetensi siswa akan berkembang secara optimal tergantung bagaimana guru memposisikan diri dan menempatkan posisi siswa dalam pembelajaran. Seharusnya, guru dalam pembelajaran lebih memposisikan diri sebagai fasilitator, motivator, dan mediator sehingga siswa dapat termotivasi mengembangkan kompetensinya untuk memperoleh hasil belajar yang maksimal. Dalam kurikulum 2004 (Depdikbud, 2004:48) menyatakan bahwa "untuk mengubah proses pembelajaran yang bersifat teoritas, berpusat pada guru, ke pembelajaran yang aktif, berpusat pada siswa".

Untuk mencapai keberhasilan pendidikan, maka proses pembelajaran di kelas harus mencerminkan proses pendidikan yang menekankan pada pencapaian tujuan belajar baik itu ranah kognitif, afektif maupun ranah psikomotor (Bloom dalam Arikunto, 2005:27). Keberhasilan proses pembelajaran ditentukan oleh beberapa faktor antara lain siswa, guru, metode, sarana dan prasarana serta situasi kelas pada saat itu. Semua faktor di atas sangat berperan penting. Guru 
dituntut menggunakan metode Pembelajaran Aktif, Inovatif, Kreatif, Efektif, dan Menyenangkan (PAIKEM). Agar proses pembelajaran berhasil, guru harus membimbing siswa dan media pembelajaran yang ada juga harus digunakan secara optimal. Selain itu diperlukan suatu model pembelajaran yang tepat, karena model pembelajaran merupakan sarana interaksi antara guru dan siswa dalam kegiatan belajar. Penggunaan model pembelajaran yang kurang tepat dapat menimbulkan kebosanan, kurang dipahami dan monoton, sehingga siswa tidak termotivasi untuk belajar.

Keberhasilan

proses

pembelajaran selain dipengaruhi oleh model pembelajaran dapat pula dipengaruhi oleh motivasi belajar siswa. Motivasi belajar dapat dipandang sebagai masukan (input) yang menjadi titik tolak dalam proses pembelajaran yang berakhir dengan suatu keluaran (output). Untuk itu, setiap awal proses pembelajaran guru sebaiknya membangun motivasi belajar yang dimiliki siswa sehingga diharapkan guru dapat menentukan bagaimana proses pembelajaran yang baik, yang sesuai dengan tujuan yang hendak dicapai. Motivasi belajar merupakan prasyarat yang dimiliki siswa agar dapat mengikuti pelajaran dengan baik.

Pendidikan Kewarganegaraan (citizenship) merupakan mata pelajaran yang memfokuskan pada pembentukan diri yang beragam dari segi agama, sosio-kultural, bahasa, usia, dan suku bangsa untuk menjadi warga negara Indonesia yang cerdas, terampil, dan berkarakter yang diamanatkan oleh Pancasila dan UUD 1945. Mata pelajaran Kewarganegaraan berfungsi sebagai wahana untuk membentuk warga negara cerdas, terampil, dan berkarakter yang setia kepada bangsa dan negara Indonesia dengan merefleksikan dirinya dalam kebiasaan berpikir dan bertindak sesuai dengan amanat Pancasila dan UUD 1945. Mata pelajaran kewarganegaraan diberikan untuk membekali siswa dengan kemampuan berpikir logis, analitis, sistematis, kritis, kreatif, serta mampu bekerjasama. Kemampuan penalaran dalam pemahaman mutlak diperlukan dalam mempelajarinya. Untuk itu, usaha menemukan cara yang dianggap terbaik untuk menyampaikan berbagai konsep yang diajarkan di sekolah perlu segera dilakukan sehingga guru diharapkan mampu menggunakan model pembelajaran yang lebih baik agar siswa termotivasi untuk berpartisipasi aktif dalam proses pembelajaran sehingga dapat meningkatkan hasil belajar siswa secara maksimal.

Salah satu masalah yang dihadapi dalam proses pembelajaran adalah rendahnya motivasi belajar siswa yang berdampak pada rendahnya pencapaian hasil belajar siswa. Salah satu penyebab rendahnya motivasi dan pencapaian hasil belajar siswa adalah masih cenderung menggunakan paradigma yang lama dimana guru memberikan pengetahuan kepada siswa yang pasif. Guru mengajar dengan metode ceramah dan mengharapkan siswa duduk, diam, dengar, catat, dan hafal $(3 \mathrm{DCH})$. Hal tersebut menyebabkan motivasi siswa untuk belajar PKn sangat kurang, tercermin dari sikap siswa seperti contoh, siswa kurang memperhatikan guru yang sedang menjelaskan di depan kelas, mengantuk karena jenuh suasana belajar tidak menyenangkan, asyik mengobrol dengan teman disampingnya. Siswa juga kurang memperhatikan suruhan-suruhan dari guru seperti suruhan untuk membentuk kelompok belajar dan aktivitas belajar siswa sangat kurang. Hal itu menunjukkan siswa banyak mengalami kesulitan-kesulitan yang berasal dari diri siswa itu sendiri yang 
disebut kesulitan internal dan kesulitan yang berasal dari luar diri siswa yang disebut kesulitan eksternal. Kesulitan internal itu berupa rendahnya kemampuan kognitif, minat, bakat, dan motivasi siswa. Kesulitan eksternal, berupa kurangnya fasilitas, tidak tepatnya strategi belajar yang diterapkan guru. Menyikapi permasalahan tersebut, sudah selayaknya dalam pembelajaran PKn dilakukan suatu inovasi yang tepat untuk membangkitkan motivasi atau gairah belajar siswa yang akan berpengaruh pada hasil belajar siswa. Melalui penelitian ini penulis mencoba menerapkan Model Pembelajaran Team Games Tournamen (TGT). Teams Games Tournament (TGT) merupakan salah satu tipe atau model pembelajaran kooperatif yang melibatkan seluruh siswa sebagai tutor sebaya, mengandung unsur permainan dan reinforcement. Pembelajaran ini di dalamnya terdapat suatu permainan akademik yang memberikan kesempatan kepada siswa untuk berkompetisi dalam upaya meningkatkan daya saing siswa. Dengan adanya daya saing akan menumbuhkan motivasi siswa untuk lebih aktif dan berupaya untuk meningkatkan hasil belajarnya, Santini (dalam Wiliyanti, 2007:21). Aktivitas belajar dengan permainan yang memungkinkan siswa dapat belajar lebih rileks disamping menumbuhkan motivasi,tanggung jawab, kejujuran, kerja sama, persaingan sehat dan keterlibatan belajar. Sehingga dengan model pembelajaran Teams Games Tournament (TGT) kita akan membentuk proses pembelajaran bermain akademik atau belajar sambil bermain. Selain itu dengan pemanfaatan media gambar dan teka-teki silang akan memungkinkan terjadinya interaksi antara guru dengan siswa, dan siswa dengan siswa untuk saling bekerjasama dalam kelompok. Media gambar merupakan media yang paling umum digunakan karena siswa cenderung lebih menyukai gambar dari pada tulisan, apalagi jika gambar itu disajikan dalam bentuk yang sesuai dan menarik. Ditambah dengan penggunaan media teka-teki silang yang mengundang rasa penasaran siswa bila tidak dapat menjawab pertanyaan dalam teka-teki silang yang diberikan. Hal ini akan menambah semangat serta motivasi siswa di dalam belajar.

Dengan cara menggunakan model pembelajaran bentuk permainan ini maka pada setiap kegiatan pembelajaran akan lebih menyenangkan, siswa dapat termotivasi untuk saling bertukar informasi, mengemukakan pendapat atau ide-ide dan dapat memberi argumentasi setiap langkah dalam menyelesaikan permasalahan khususnya dalam pembelajaran PKn dengan menggunakan gambar, teka teki silang berupa pertanyaanpertanyaan yang berkaitan dengan materi dan reward bagi kelompok yang memperoleh skor tertinggi. Dengan adanya pengungkapan ideide maka siswa ikut terlibat secara aktif dalam pembelajaran dan memiliki kemampuan berkomunikasi yang memadai. Serta memiliki motivasi dan hasil belajar yang tinggi dalam pelajaran.

Berdasarkan uraian diatas, maka yang terdapat beberapa permasalahan yang layak dikedepankan, yaitu: (1) Apakah penerapan model pembelajaran Kooperatif Tipe Teams Games Tournament (TGT) berbantuan media gambar dan teka-teki silang dapat meningkatkan motivasi belajar mata pelajaran PKn siswa Kelas VIII.6 SMP Negeri 3 Banjar Tahun Ajaran 2013/2014 ?, (2) Apakah penerapan model pembelajaran Kooperatif Tipe Teams Games Tournament (TGT) berbantuan media gambar dan tekateki silang dapat meningkatkan hasil belajar mata pelajaran PKn siswa 
Kelas VIII.6 SMP Negeri 3 Banjar Tahun Ajaran 2013/2014 ?, (3) Bagaimana kendala-kendala yang dihadapi dalam penerapan model pembelajaran Teams Games Tournament (TGT) berbantuan media gambar dan teka-teki silang pada siswa Kelas VIII.6 SMP Negeri 3 Banjar Tahun Ajaran 2013/2014 dan alternatif pemecahan masalahnya?

\section{METODE PENELITIAN}

Penelitian ini merupakan Penelitian Tindakan Kelas dengan menerapkan model pembelajaran kooperatif tipe Teams Games Tournament (TGT) yang bertujuan untuk memperbaiki, meningkatkan motivasi dan hasil belajar siswa dalam pembelajaran PKn dilakukan di kelas VIII.6 pada semester II tahun pelajaran 2013/2014 bertempat SMP Negeri 3 Banjar.

Adapun rancangan yang dipilih atau dipergunakan dalam penelitian tindakan kelas ini adalah rancangan penelitian yang diadaptasi dari model Suharsimi Arikunto 2008, yang terdiri dari beberapa tahapan yang dilakukan diantaranya perencanaan, pelaksanaan tindakan, observasi dan evaluasi serta refleksi tindakan. Dalam pelaksanaan tahapan-tahapan tersebut akan merupakan suatu siklus yaitu tindakan yang terus menerus dilaksanakan untuk mencapai tujuan dalam meningkatkan motivasi dan hasil belajar PKn.

Subjek penelitian adalah benda, hal atau tempat variabel melekat dan yang paling penting dalam penelitian, karena pada subjek penelitian itulah data tentang variabel yang akan diteliti adalah siswa kelas VIII.6 SMP Negeri 3 Banjar Kabupaten Buleleng, yang berjumlah 29 orang dengan rincian 17 orang laki-laki dan 12 orang perempuan. Alasan pengambilan subyek penelitian ini karena 1) pembelajaran PKn di kelas ini lebih didominasi oleh metode ceramah sehingga siswa tidak termotivasi mengikuti proses pembelajaran, 2) Hasil belajar PKn masih sangat rendah.

Wendra (dalam Miyasa 2011:44) menyatakan bahwa objek penelitian dibedakan menjadi dua, yaitu objek yang mencerminkan proses dan objek yang mencerminkan produk/hasil. Objek yang mencerminkan proses adalah objek yang mencangkup tindakan yang akan dilakukan dan materi yang akan diberikan. Objek yang mencerminkan produk mencakup apa yang ingin diperbaiki. Jadi objek penelitian ini adalah motivasi dan hasil belajar siswa melalui penerapan model pembelajaran kooperatif tipe Teams Games Tournament (TGT) berbantuan media gambar dan tekateki silang.

Pengumpulan data dalam penelitian ini menggunakan beberapa teknik antara lain : lembar observasi dan pemberian tes hasil belajar. Jenis teknik dan alat pengumpulan data dapat dilihat dalam tabel berikut: Tabel. Jenis Data dan Instrument Penelitian

\begin{tabular}{|l|l|l|l|}
\hline No & Jenis data & $\begin{array}{l}\text { Instrument } \\
\text { penelitian }\end{array}$ & $\begin{array}{l}\text { Waktu } \\
\text { pelaksanaan }\end{array}$ \\
\hline 1 & $\begin{array}{l}\text { Motivasi } \\
\text { belajar } \\
\text { PKn } \\
\text { siswa }\end{array}$ & $\begin{array}{l}\text { Pedoman } \\
\text { observasi }\end{array}$ & $\begin{array}{l}\text { Setiap } \\
\text { pembelajaran }\end{array}$ \\
\hline 2 & $\begin{array}{l}\text { Hasil } \\
\text { belajar } \\
\text { PKn } \\
\text { siswa }\end{array}$ & $\begin{array}{l}\text { Tes hasil } \\
\text { belajar }\end{array}$ & $\begin{array}{l}\text { Pada akhir } \\
\text { siklus }\end{array}$ \\
\multicolumn{3}{|c|}{ Setelah data terkumpul, } \\
adalah
\end{tabular}

menganalisis atau mengolah data. Teknik yang digunakan dalam menganalisis data motivasi belajar PKn siswa adalah analisis deskriftif kuantitatif. Teknik analisis deskriftif kuantitatif adalah suatu yang menggunakan paparan sederhana dalam bentuk angka-angka dan presentase. Data hasil belajar siswa dianalisis secara deskriptif kuantitatif yaitu dengan mencari skor hasil belajar dari tes akhir siklus.

Indikator

Keberhasilan

Tindakan dengan penerapan model 
pembelajaran kooperatif tipe TGT berbantuan media gambar dan tekateki silang adalah untuk menangkar sebuah penelitian perlu ditetapkan indikator atau parameter keberhasilan itu sendiri. Pada konteks penelitian ini indikator keberhasilam tindakan akan dihentikan atau dikatakan berhasil manakala motivasi belajar siswa dilihat dari skor motivasi belajar siswa berada pada kategori termotivasi, hasil belajar siswa pada tiap siklus mengalami peningkatan dan minimal 25 orang siswa berada pada Kriteria Ketuntasan Minimal (KKM) yaitu 75 dan kriteria penggolongan yang telah ditetapkan. Hasil penelitian ini menunjukkan bahwa penerapan model pembelajaran TGT (Teams Games Tournament) berbantuan media gambar dan teka-teki silang dalam pembelajaran $\mathrm{PKn}$ pada siswa kelas VIII 6 SMP Negeri 3 Banjar, dapat meningkatkan motivasi dan hasil belajar PKn. Hal ini dapat dilihat dari data berikut ini: 1) terjadi peningkatan skor rata-rata motivasi belajar PKn siswa siklus I sebesar $46,8 \%$ dan tergolong cukup termotivasi sedangkan skor rata-rata motivasi belajar PKn siklus II sebesar $69,7 \%$ dan tergolong termotivasi, 2) terjadi peningkatan nilai rata-rata hasil belajar PKn siswa pada siklus I sebesar 74,4 dengan daya serap yaitu $74,4 \%$ dan ketuntasan belajar secara klasikal mencapai $68,9 \%$, sedangkan nilai rata-rata hasil belajar PKn siswa pada siklus II sebesar 83,9 dengan daya serap yaitu $83,9 \%$ dan ketuntasan belajar secara klasikal mencapai 100\%.

\section{HASIL PENELITIAN DAN PEMBAHASAN}

3.1 Motivasi dan Hasil Belajar PKn Siswa pada siklus I dengan menggunakan model

Pembelajaran Kooperatif Tipe TGT berbantuan media Gambar dan Teka-Teki Silang

\section{di kelas VIII 6 SMP Negeri 3 Banjar}

\section{1) Motivasi Belajar Siklus I}

Berdasarkan hasil analisis data motivasi belajar pada siklus I nampak bahwa perolehan hasil motivasi belajar siswa pada tiap pertemuan mengalami peningkatan, pada pertemuan pertama rata-rata $43,4 \%$, dan pertemuan kedua menjadi $50,3 \%$, sehingga rata-rata siklus I sebesar $46,8 \%$ dan motivasi belajar secara klasikal berada pada kategori cukup termotivasi. Pada siklus I ini motivasi belajar PKn siswa belum berada pada kategori termotivasi, sehingga penelitian ini dilanjutkan pada siklus II dengan harapan terjadi peningkatan motivasi belajar PKn siswa.

Tabel. Sebaran Skor Motivasi Siswa pada Siklus I

\begin{tabular}{|l|l|l|l|}
\hline No & \multicolumn{1}{|c|}{ Kategori } & \multicolumn{2}{|c|}{ Siklus I } \\
\cline { 3 - 4 } & & $\begin{array}{l}\text { Jumlah } \\
\text { Siswa }\end{array}$ & Persentase \\
\hline 1 & $\begin{array}{l}\text { Sangat } \\
\text { Termotivasi }\end{array}$ & - & - \\
\hline 2 & Termotivasi & 2 & $6,8 \%$ \\
\hline 3 & $\begin{array}{l}\text { Cukup } \\
\text { Termotivasi }\end{array}$ & 22 & $75,8 \%$ \\
\hline 4 & $\begin{array}{l}\text { Kurang } \\
\text { Termotivasi }\end{array}$ & 5 & $17,2 \%$ \\
\hline 5 & $\begin{array}{l}\text { Sangat Kurang } \\
\text { Termotivasi }\end{array}$ & - & - \\
\hline \multicolumn{2}{|l|}{ Jumlah } & 29 Orang & \\
\hline \multicolumn{2}{|l}{ Rata-rata } & $46,8 \%$ & \\
\hline
\end{tabular}

Pada siklus I ini motivasi belajar PKn siswa belum berada pada kategori termotivasi, sehingga penelitian ini dilanjutkan pada siklus II dengan harapan terjadi peningkatan motivasi belajar PKn siswa.

\section{2) Hasil Belajar Siklus I}

Berdasarkan hasil analisis data hasil belajar siswa siklus I nilai ratarata hasil belajar PKn siswa pada siklus I sebesar 74,4 dengan daya serap yaitu $74,4 \%$ dan ketuntasan belajar secara klasikal mencapai $68,9 \%$, 
Tebel.

Presentase

Katagori

Ketuntasan Hasil Belajar Individual Pada Siklus I Kelas VIII 6 SMP Negeri 3 Banjar

\begin{tabular}{|c|c|c|c|c|c|c|}
\hline $\begin{array}{l}\mathrm{N} \\
\mathrm{O}\end{array}$ & Kategori & $\mathrm{Jml}$ & $\begin{array}{l}\text { Prese } \\
\text { ntase }\end{array}$ & $\begin{array}{l}\text { Presenta } \\
\text { se } \\
\text { Keseluru } \\
\text { han }\end{array}$ & $\begin{array}{l}\text { Jumlah } \\
\text { Siswa } \\
\text { Tuntas }\end{array}$ & $\begin{array}{l}\text { Keter } \\
\text { angan }\end{array}$ \\
\hline 1 & $\begin{array}{l}\text { Sangat } \\
\text { Baik }\end{array}$ & - & - & - & \multirow{2}{*}{$\begin{array}{l}20 \text { orang } \\
\text { siswa } \\
\text { berada } \\
\text { dalam } \\
\text { kategori } \\
\text { tuntas }\end{array}$} & \multirow{5}{*}{$\begin{array}{l}\text { Belum } \\
\text { menc } \\
\text { apai } \\
\text { KKM } \\
\text { dilanju } \\
\text { tkan } \\
\text { ke } \\
\text { siklus } \\
\text { ॥ }\end{array}$} \\
\hline 2 & Baik & 20 & $68,9 \%$ & $68,9 \%$ & & \\
\hline 3 & Cukup & 9 & $31 \%$ & $31 \%$ & \multirow{3}{*}{$\begin{array}{l}9 \text { orang } \\
\text { siswa } \\
\text { berada } \\
\text { dalam } \\
\text { kategori } \\
\text { belum } \\
\text { tuntas } \\
\end{array}$} & \\
\hline 4 & Kurang & - & - & - & & \\
\hline 5 & $\begin{array}{l}\text { Sangat } \\
\text { Kurang }\end{array}$ & - & - & $\begin{array}{ll}- & - \\
-1\end{array}$ & & \\
\hline \multicolumn{2}{|c|}{ Jumlah } & 29 & $100 \%$ & $100 \%$ & & \\
\hline
\end{tabular}

Berdasarkan tabel diatas presentase ketuntasan hasil belajar siswa kelas VIII 6 SMP Negeri 3 Banjar, siswa yang tuntas 20 orang dengan presentase $68,9 \%$ dan siswa yang tidak tuntas 9 orang dengan presentase $31 \%$. Dengan demikian Ketuntasan Belajar (KB) belum terpenuhi, karena KB pada siklus I masih kurang dari $85 \%$. Sehingga penelitian ini harus dilanjutkan pada siklus II.

Dalam proses pembelajaran masih ada beberapa kendala yang terjadi selama tindakan siklus I seperti yang dipaparkan pada refleksi siklus I. Tindakan perbaikan yang dilakukan untuk mengatasi kendala yang ditemui pada siklus I adalah:

1) Sebelum melaksanakan pembelajaran pada siklus II, guru memberikan penekanan kembali mengenai proses pembelajaran yang diterapkan. Memberi tahu materi yang akan dibahas berikutnya kepada siswa, hal ini dilakukan supaya siswa dapat membaca dan mencermati lebih awal tentang kegiatan pembelajaran yang akan dilalakukan berikutnya. Siswa juga dapat mempersiapkan diri memahami materi yang akan dibahas sehingga kegiatan pembelajaran bisa berjalan lebih optimal.
2) Selain itu, guru melakukan wawancara kepada siswa mengenai kesulitan-kesulitan yang dialami selama proses pembelajaran dan mendiskusikan pemecahan masalahnya dengan guru mata pelajaran. Menciptakan proses pembelajaran yang menyenangkan dengan cara memberikan motivasi kepada siswa untuk lebih aktif lagi dalam pembelajaran.

3) Diusahakan pada saat melakukan diskusi siswa tidak terlalu lama mengabiskan waktu untuk melakukan hal-hal diluar pembelajaran sehingga waktu yang ada bisa dimanfaatkan sebaik mungkin. Selain itu diupayakan pengawasan yang lebih intensif terhadap siswa agar mereka tidak membicarakan hal-hal diluar materi pada saat melakukan diskusi.

4) Guru menjelaskan kembali mengenai sistem penilaian afektif, kognitif, dan psikomotor. Penjelasan teknik penilaian ini diharapkan dapat memotivasi siswa baik dalam kelompok maupun individu.

5) Guru harus benar-benar bisa dan tegas dalam mengkondisikan waktu selama $2 \times 40$ menit pelajaran agar semua tahap model pembelajaran TGT dapat dilalui dengan sempurna.

3.2 Motivasi dan Hasil Belajar PKn Siswa pada siklus II dengan menggunakan model Pembelajaran Kooperatif Tipe TGT berbantuan media Gambar dan Teka-Teki Silang di kelas VIII 6 SMP Negeri 3 Banjar

\section{1) Motivasi Belajar Siklus II}

Berdasarkan perbaikan tindakan siklus I, maka hasil analisis data motivasi belajar pada siklus II 
nampak bahwa nilai motivasi belajar PKn siklus II mengalami peningkatan setiap pertemuannya. Pada pertemuan pertama rata-rata motivasi belajar PKn siswa sebesar 65,2\% kemudian meningkat pada pertemuan kedua menjadi $74,3 \%$ sehingga rata-rata motivasi siklus II menjadi $69,7 \%$ dan berada pada kategori termotivasi.

Tabel. Sebaran Skor Motivasi Siswa Pada Siklus II

\begin{tabular}{|c|l|l|l|}
\hline \multirow{2}{*}{$\begin{array}{c}\text { N } \\
0\end{array}$} & \multicolumn{1}{|c|}{ Kategori } & \multicolumn{2}{|c|}{ Siklus II } \\
\cline { 3 - 4 } & $\begin{array}{l}\text { Jumlah } \\
\text { Siswa }\end{array}$ & Presentase \\
\hline 1 & Sangat Termotivasi & 4 & $13,7 \%$ \\
\hline 2 & Termotivasi & 23 & $79,3 \%$ \\
\hline 3 & Cukup Termotivasi & 2 & $6,8 \%$ \\
\hline 4 & Kurang Termotivasi & - & - \\
\hline 5 & $\begin{array}{l}\text { Sangat Kurang } \\
\text { Termotivasi }\end{array}$ & - & - \\
\hline Jumlah & 29 Orang & \\
\hline \multicolumn{2}{|l|}{ Rata-rata } & $69,7 \%$ \\
\hline
\end{tabular}

Pada siklus II ini motivasi belajar PKn siswa sudah memenuhi kriteria yang sudah ditetapkan karena sudah berada pada kategori termotivasi.

\section{2) Hasil Belajar Siklus II}

Berdasarkan hasil analisis data hasil belajar pada siklus II nilai ratarata hasil belajar PKn siswa pada siklus II sebesar 83,9 dengan daya serap yaitu $83,9 \%$ dan ketuntasan belajar secara klasikal mencapai $100 \%$.

Tebel. Presentase Katagori Ketuntasan Hasil Belajar Individual Pada Siklus II Kelas VIII 6 SMP Negeri 3 Banjar

\begin{tabular}{|c|c|c|c|c|c|c|}
\hline $\begin{array}{l}\mathrm{N} \\
\mathrm{O}\end{array}$ & Kategori & $\mathrm{Jml}$ & $\begin{array}{l}\text { Prese } \\
\text { ntase }\end{array}$ & $\begin{array}{l}\text { Present } \\
\text { ase } \\
\text { Keselur } \\
\text { uhan }\end{array}$ & $\begin{array}{l}\text { Jumlah } \\
\text { Siswa } \\
\text { Tuntas }\end{array}$ & $\begin{array}{l}\text { Ketera } \\
\text { ngan }\end{array}$ \\
\hline 1 & $\begin{array}{l}\text { Sangat } \\
\text { Baik }\end{array}$ & 18 & $\begin{array}{l}62,06 \\
\%\end{array}$ & $62,06 \%$ & \multirow{2}{*}{$\begin{array}{l}29 \text { orang } \\
\text { siswa } \\
\text { berada } \\
\text { dalam } \\
\text { kategori } \\
\text { tuntas }\end{array}$} & \multirow{2}{*}{$\begin{array}{l}\text { Sudah } \\
\text { menca } \\
\text { pai } \\
\text { KKM }\end{array}$} \\
\hline 2 & Baik & 11 & $\begin{array}{l}37,9 \\
\%\end{array}$ & $37,9 \%$ & & \\
\hline 3 & Cukup & - & - & - & & \\
\hline 4 & Kurang & - & - & - & & \\
\hline 5 & $\begin{array}{l}\text { Sangat } \\
\text { Kurang }\end{array}$ & - & - & - & & \\
\hline \multicolumn{2}{|c|}{ Jumlah } & 29 & $100 \%$ & $100 \%$ & & \\
\hline
\end{tabular}

kriteria yang telah ditetapkan, maka ketuntasan belajar siswa secara klasikal sudah memenuhi kriteria $\geq$ $85 \%$. Rata-rata tes hasil belajar PKn siswa pada siklus II adalah 83,9 dengan daya serap (DS) $83,9 \%$ dan ketuntasan klasikal (KB) 100\%. Berdasarkan kategori keberhasilan, penelitian dikatakan berhasil jika ratarata siswa lebih besar atau sama dengan 75 dan ketuntasan belajar minimal $85 \%$. Berdasarkan kriteria tersebut maka tes hasil belajar PKn siswa pada siklus II sudah berhasil memenuhi kriteria ketuntasan secara klasikal yaitu $85 \%$.

Tabel. Ringkasan Data Motivasi Belajar dan Hasil Belajar PKn Siswa Kelas VIII 6 SMP Negeri 3 Banjar Tahun Ajaran 2013/2014

\begin{tabular}{|c|c|c|}
\hline \multirow{2}{*}{ Hasil Penelitian } & \multicolumn{2}{|c|}{ Siklus } \\
\cline { 2 - 3 } & I & II \\
\hline Motivasi Belajar & $46,8 \%$ & $69,7 \%$ \\
\hline $\begin{array}{c}\text { Rata-rata Hasil } \\
\text { Belajar }\end{array}$ & $74,4 \%$ & $83,9 \%$ \\
\hline Daya Serap & $74,4 \%$ & $83,9 \%$ \\
\hline $\begin{array}{c}\text { Ketuntasan Belajar } \\
\text { Klasikal }\end{array}$ & $68,9 \%$ & $100 \%$ \\
\hline Kategori & $\begin{array}{c}\text { Belum } \\
\text { Tuntas }\end{array}$ & Tuntas \\
\hline
\end{tabular}

Tabel diatas menunjukkan bahwa, terjadi perbandingan peningkatan skor rata-rata motivasi belajar PKn pada siklus I adalah $46,8 \%$ dengan kategori cukup termotivasi dan pada siklus II skor rata-rata motivasi belajar $69,9 \%$ berada pada kategori termotivasi. Perbandingan rata-rata hasil tes belajar PKn pada siklus I adalah daya serap siswa $74,4 \%$ dan ketuntasan belajar klasikal 68,9\% jika dibandingkan dengan kriteria ketuntasan belajar dikatakan belum tuntas karena masih dibawah $85 \%$. Sedangkan, rata-rata skor hasil tes PKn pada siklus II adalah daya serap $83,9 \%$ dan ketuntasan belajar klasikal $100 \%$ dengan katagori tuntas. Terbukti bahwa motivasi belajar mengalami peningkatan dari kategori cukup termotivasi pada siklus I menjadi termotivasi pada siklus II dan hasil belajar PKn secara individu mengalami peningkatan dari 
katagori belum tuntas pada siklus I menjadi tuntas pada siklus II.

\subsection{Kendala-kendala dihadapi oleh siswa dalam pembelajaran Kooperatif Tipe TGT di kelas VIII 6 SMP Negeri 3 Banjar serta solusi yang diberikan}

Antara lain:

1. Dalam penerapan model pembelajaran TGT ini memerlukan waktu yang lama, sehingga setiap pertemuan dengan waktu pembelajaran $2 \mathrm{x}$ 40 menit masih sangat kurang sehingga pembelajaran kurang maksimal. Guru harus benarbenar bisa dan tegas dalam mengkondisikan waktu selama 2 x 40 menit pelajaran agar semua tahap model pembelajaran TGT dapat dilalui dengan sempurna.

2. Siswa masih ada yang ribut saat melakukan diskusi dan tournament. Untuk mensiasati hal tersebut bisa dilakukan dengan memberikan perhatian lebih pada siswa tertentu yang ribut/motivasinya kurang, baik dengan memberikan pertanyaan dan nasehat, selain itu juga dalam pelaksanaan pambelajaran guru sebagai fasilitator berkeliling untuk mengawasi proses diskusi kelas maupun kelompok serta memimpin/mengarahkan jalannya tournament.

3. Kemampuan siswa sedikit kurang dalam mengikuti tahapan-tahapan pembelajaran dengan model Teams Games Tournament sehingga tahapan pembelajaran harus dijelaskan secara bertahap dan intensif. Bagi siswa model pembelajaran seperti ini baru diterapkan dalam pembelajaran PKn. Karena menerapkan model pembelajaran baru kepada siswa sangat sulit, siswa diharuskan mengubah pola pikir mereka dengan mengikuti langkahlangkah penerapan model pembelajaran yang digunakan oleh guru (peneliti), tentu dalam hal ini kendala-kendala tersebut dapat diperkecil sehingga siswa mendapatkan hasil belajar yang optimal.

\section{PENUTUP}

Berdasarkan hasil penelitian dan pembahasan, maka dapat diambil suatu kesimpulan sebagai berikut: Penerapan model pembelajaran kooperatif tipe Teams Games Tournament (TGT) berbantuan Media Gambar dan Teka-Teki Silang dapat meningkatkan motivasi belajar PKn siswa kelas VIII 6 SMP Negeri 3 Banjar Tahun Ajaran 2013/2014. Hal ini dapat dilihat dari hasil rata-rata motivasi belajar PKn siswa pada siklus I sebesar 46,8\% dengan kategori cukup termotivasi dan pada siklus II hasil rata-rata motivasi belajar PKn siswa sebesar 69,7\% dengan kategori termotivasi. Jadi dapat dikatakan bahwa terjadi peningkatan motivasi belajar PKn siswa sebesar $22,9 \%$.

Penerapan model pembelajaran Teams Games Tournament (TGT) berbantuan Media Gambar dan TekaTeki Silang dapat meningkatkan hasil belajar PKn siswa siswa kelas VIII 6 SMP Negeri 3 Banjar Tahun Ajaran 2013/2014. Hal ini dapat dilihat dari hasil belajar siswa pada siklus I dengan rata-rata sebesar 74,4 termasuk dalam kategori cukup baik dengan daya serap $74,4 \%$, ketuntasan klasikal 69,9\% dan ketuntasan individu sebanyak 20 orang. Pada siklus II dengan rata-rata sebesar 83,9 termasuk dalam kategori baik, dengan daya serap $83,9 \%$, ketuntasan klasikal $100 \%$ dan ketuntasan individu sebanyak 29 orang. Jadi rata-rata hasil belajar pada siklus I sampai dengan siklus II mengalami peningkatan sebesar 9,5.

Dengan mempertimbangkan berbagai kelebihan dan kekurangan 
Model Pembelajaran Kooperatif Tipe Teams Games Tournament (TGT) pada hasil temuan penelitian ini, saran-saran yang dapat diberikan yaitu sebagai berikut :

1. Model pembelajaran Teams Games Tournament (TGT) berbantuan media gambar dan teka-teki silang dapat digunakan sebagai salah suatu alternatif model pembelajaran dalam upaya meningkatkan hasil belajar PKn siswa. Untuk itu, kepada guru khususnya guru $\mathrm{PKn}$, disarankan untuk mencoba menerapkan model pembelajaran Teams Games Tournament dapat membantu siswa untuk mengembangkan keterampilan dan kreativitasnya baik dalam proses pembelajaran maupun di luar proses pembelajaran.

2. Guru diharapkan meningkatkan kemampuan dalam membuat keputusan nilai, menguasai materi pembelajaran sebelum mengajar, serta memberi reinforcement yang variatif, kontekstual, dan bermakna yang dapat mengarahkan ke tujuantujuan belajar peningkatan hasil belajar dan motivasi siswa.

3. Bagi calon peneliti lainnya disarankan untuk mengadakan penelitian lebih lanjut mengenai model pembelajaran Teams Games Tournament. Hasil penelitian ini bisa dijadikan acuan dalam mencermati kelebihan dan kekurangan yang ditemukan sehingga akan lebih menyempurnakan hasil penelitian berikutnya.

\section{DAFTAR PUSTAKA}

Arikunto, Suharsimi. 2008. DasarDasar Evaluasi Pendidikan (edisi revisi). Jakarta: Bumi Aksara.
Arsyad, Azhar. 2013. Media Pembelajaran (edisi revisi). Jakarta : Rajawali Pers.

Daryanto dan Mulyo. 2012. Model Pembelajaran Indovatif. Yogyakarta: Penerbit Gava Media.

Hardiwati, Yovita. 2013. 101 Strategi Untuk Mengajar Secara Aktif. Jakarta: PT Indeks Permata Puri Media.

Depdiknas. 2005. Pendidikan Kewarganegaraan,

Kurikulum dan Silabus

Pendidikan

Kewarganegaraan. Jakarta : Depdiknas.

Hidayat, K dan Arsa, A. 2008. Pendidikan

Kewarganegaraan. Jakarta: Predana Media Group.

Rusman. 2010. Model-model Pembelajaran

Mengembangkan

Profesionalisme

Guru. Jakarta. PT Rajagrafindo Persada.

Sardiman, A.M. 2012. Interaksi dan Motivasi Belajar Mengajar. Jakarta: Rajawali Pers.

Trianto, 2009. Mendesain Model pembelajaran InovatifProgresif. Jakarta: PT Fajar Interpratama Mandiri. 